\title{
Kirurška patologija
}

\section{Surgical pathology}

\author{
Dora Fučkar Čupić
}

\begin{abstract}
Sažetak. Kirurška patologija najznačajniji je i vremenski najzahtjevniji dio prakse većine patologa. Ima za cilj dati/isključiti definitivnu dijagnozu bolesti temeljeći se na uzorcima tkiva. Dva su glavna tipa tkivnih uzoraka za patološku analizu: biopsije i kirurške resekcije. Četiri su glavna dijela kirurške patologije koji se koriste u konačnoj dijagnostici tkivnih uzoraka: makroskopski pregled, patohistološki pregled koji se temelji na svjetlosnoj mikroskopiji, imunohistokemija i molekularne/citogenetske analize. Rezultat rada patologa je patohistološko izvješće. Ono sadrži makroskopski i mikroskopski opis lezije, dijagnozu ili diferencijalnu dijagnozu. Postoje situacije kada je potrebno dijagnozu postaviti za vrijeme kirurškog zahvata, dok je pacijent pod anestezijom. Tada se koristi hitna ili intraoperacijska biopsija, na smrznutim tkivnim rezovima. Hitna ili intraoperacijska biopsija je hitno stanje u patologiji koje zahtijeva dobru suradnju između kirurga i patologa te iskusnog i dobro educiranog patologa koji je svjestan mogućnosti, ali i ograničenja hitne biopsije. Resekcijski rubovi su rubovi ili površine koje je napravio kirurg. Udaljenost između tumora i resekcijskog ruba naziva se kirurški rub. Kirurški rubovi izuzetno su važni jer pozitivnost rubova korelira s recidivom bolesti. Definicija pozitivnog kirurškog ruba ovisi o vrsti tumora, njegovoj biologiji i lokalizaciji bolesti. Jedan od najvažnijih ciljeva kirurške patologije je dijagnostika malignih bolesti i procjena proširenosti bolesti, odnosno klasifikacija tumora, prema odrednicama Svjetske zdravstvene organizacije. Patološka klasifikacija (p) malignih bolesti označava se kao pTNM (primarni tumor - T, regionalni limfni čvorovi $-\mathrm{N}$, udaljene metastaze $-\mathrm{M}$ ). Ona se temelji na podacima dobivenim prije kirurškog liječenja uz modifikaciju proizašlu iz patohistološke analize tkiva.
\end{abstract}

Ključne riječi: biopsija; kirurška patologija; proširenost bolesti; resekcijski rubovi; smrznuti rezovi; TNM klasifikacija

\begin{abstract}
The most important part of pathology work is surgical pathology. Its goal is to diagnose or exclude the clinical diagnosis based on tissue samples. Two main types of tissue samples for pathohistologic analyses are biopsies and surgical resections. There are four main parts used in final diagnosis of tissue samples in surgical pathology: macroscopic exam, pathohistologic analysis, immunohistochemistry and molecular/cytogenetic analysis. The result of pathologists' work is pathohistologic report, which contains macroscopic and microscopic description of a lesion, diagnosis or differential diagnosis. There are situations when diagnosis needs to be established during surgical procedure, while the patient is under anesthesia, so pathologist uses so called intraoperative biopsy or frozen tissue sections. This is an emergency in pathology practice and it requires good cooperation between surgeons and pathologists. The surgical margins are surfaces that were cut by the surgeon. The distance between the tumour and the margin is called surgical margin. Margins are important as an incompletely removed disease process may lead to reccurrence. What defines a positive surgical margin is dependent on the tumour and its biology; definitions of positive margin are dependent on the anatomical site. One of the most important goals of surgical pathology is diagnosis of malignant diseases and assessment of extent of disease, and not less important, tumour classification, defined by World Health Organization. Pathological classification (p) of malignant diseases (or postsurgical pathohistologic classification) is defined as PTNM ( $\mathrm{T}$ - tumour, $\mathrm{N}$ - lymph node, $\mathrm{M}$ - distant metastasis). It is based on presurgical clinical data modified by pathohistological data analysis.
\end{abstract}

Key words: biopsy; extent of disease; frozen sections; resection margins; surgical pathology; TNM classification
Zavod za patologiju i patološku anatomiju, Medicinski fakultet Sveučilišta u Rijeci, Rijeka

\section{Dopisni autor:}

Dr. sc. Dora Fučkar Čupić, dr. med. Zavod za patologiju i patološku anatomiju, Medicinski fakultet Sveučilišta u Rijeci Braće Branchetta 20, 51000 Rijeka e-mail: dorica9@gmail.com

http://hrcak.srce.hr/medicina 


\section{UVOD}

Kirurška patologija najznačajniji je i vremenski najzahtjevniji dio prakse većine patologa. Ima za cilj dati definitivnu dijagnozu bolesti (ili je isključiti) temeljeći se na uzorcima tkiva.

\section{VRSTE TKIVNIH UZORAKA ZA PATOLOŠKU ANALIZU}

Dvije su glavne vrste tkivnih uzoraka za patološku analizu: biopsije i kirurške resekcije.

Kirurška patologija je najznačajniji dio prakse patologa s ciljem postavljanja dijagnoze na uzorcima tkiva. Dva su glavna tipa uzoraka: biopsije i kirurške resekcije. Biopsije su mali komadići tkiva. Postoji više vrsta biopsija: biopsije širokom iglom, incizijske i ekscizijske biopsije. Uzorci kirurških resekcija dobivaju se terapijskim kirurškim odstranjenjem čitavog oboljelog područja, organa ili multiplih organa.

\section{Biopsije}

Biopsije su mali komadići (isječci) tkiva primarno odstranjeni u svrhu kirurško-patološke dijagnostike. Postoji više vrsta biopsija:

- Biopsije širokom iglom (tzv. CB; engl. core biopsy) koje se dobivaju pod vodstvom radioloških tehnika kao što su ultrazvuk, kompjutorizirana tomografija (CT) ili magnetska rezonancija (MR); biopsije širokom iglom (slika 1), u kojima je očuvana tkivna arhitektura, ne treba miješati s uzorcima dobivenim aspiracijom tankom iglom (tzv. FNA; engl. fine needle aspiration), pri čemu se dobiva aspirirani uzorak tkiva/stanica ili tkivnih tekućina i analiziraju se stanice bez očuvane arhitekture tkiva, koje analiziraju specijalisti citolozi, uz korištenje citoloških tehnika.

- Incizijske biopsije dobivaju se tijekom kirurških postupaka pri čemu se odstranjuje dio sumnjive tvorbe, $u$ isključivo dijagnostičke svrhe; pri tome se koriste razna bioptička kliješta:

- „pinch” biopsija: bioptička metoda u dijagnostici gastrointestinalne patologije, u kojoj se koristi pinceta („forceps") tijekom endoskopije, radi dohvaćanja i rezanja malih uzoraka tkiva građenih od epitela sluznice i lamine proprije;

- „punch” biopsija: bioptička metoda u dijagnostici patologije kože (novotvorine, pigmentirane lezije, inflamatorne lezije i kronični kožni poremećaji) i sluznice vrata maternice (preneoplastične i neoplastične lezije), pri čemu se dobivaju uzorci tkiva građeni od pune debljine kože i sluznice.

- Ekscizijske biopsije dobivaju se tijekom kirurških postupaka pri čemu se odstranjuju sumnjive tvorbe u cijelosti, $u$ dijagnostičke i/ili terapijske svrhe.

Ekscizijske biopsije kožnih lezija, konizati vrata maternice i ekscizije gastrointestinalnih polipa (slika 2) vrlo su učestale. Ako su resekcijski rubovi u ekscizijskoj biopsiji uredni, tada se radi o dijagnostičkoj i terapijskoj biopsiji.

Patološka interpretacija biopsija je kritična u postavljanju dijagnoze benignih ili malignih tumora i može diferencirati različite tipove i graduse malignih tumora, kao i odrediti njihove specifične molekularne puteve progresije. Biopsije uključuju i netumorske dijagnoze, kao što su inflamatorne, infektivne ili idiopatske bolesti.

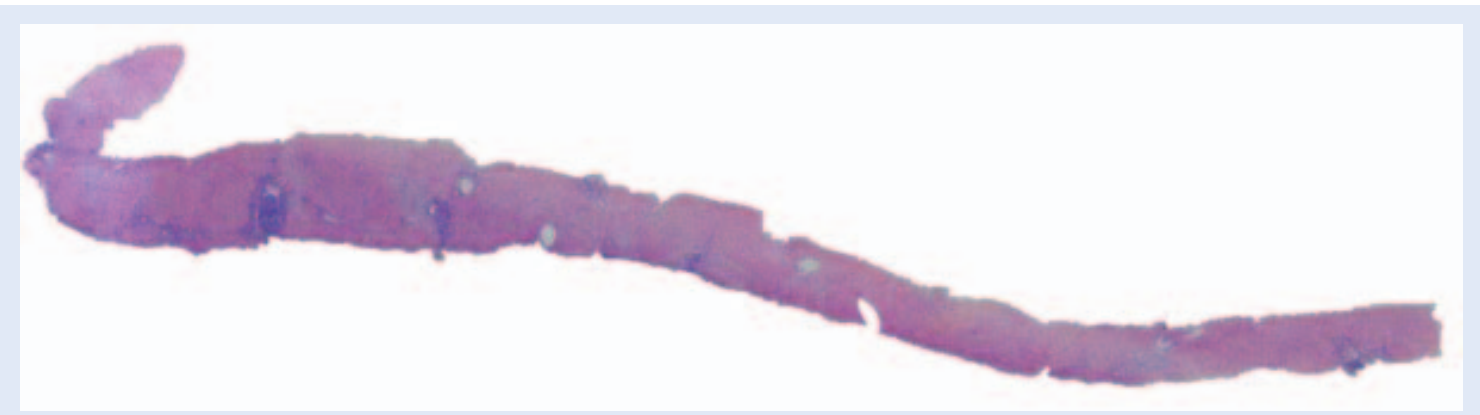

Slika 1. Histološki preparat bioptičkog uzorka tkiva dobivenog biopsijom širokom iglom. Preparat je duljine $10 \mathrm{~mm}$, širine 1 do $1,5 \mathrm{~mm}$. 
Ove informacije važne su zbog procjene pacijentove prognoze i odabira odgovarajuće terapije.

\section{Kirurške resekcije}

Uzorci kirurških resekcija dobivaju se terapijskim kirurškim odstranjenjem čitavog oboljelog područja, organa ili multiplih organa (slika 3).

Cilj ovakvih postupaka je često definitivni kirurški tretman bolesti u kojih već postoji dijagnoza ili je dijagnoza vrlo vjerojatna.

Osim toga, patološka analiza ovakvih uzoraka važna je zbog određivanja stadija maligne bolesti, kirurških rubova, identifikacije eventualne prisutnosti još neke bolesti, te procjene postoperacijskog (adjuvantnog) ili preoperacijskog (neoadjuvantnog) liječenja.

HITNA BIOPSIJA (INTRAOPERACIJSKA BIOPSIJA NA SVJEŽEM SMRZNUTOM TKIVU - SMRZNUTI REZOVI)

Postoje situacije kada je potrebno dijagnozu postaviti za vrijeme kirurškog zahvata, dok je pacijent pod anestezijom ${ }^{1}$. Tada se koristi hitna ili intraoperacijska biopsija, na smrznutim tkivnim rezovima.

Razlog za hitnu biopsiju je brza mikroskopska dijagnoza koja usmjerava intra- ili perioperacijski smjer daljnjeg terapijskog postupka². Najčešće je potrebno:

- identificirati prirodu lezije (benigni ili maligni tumor);

- procijeniti status kirurških rubova (posebno u kirurgiji glave i vrata);

- identificirati postojanje metastaza u limfnim čvorovima;

- identificirati podrijetlo tkiva (npr. paratireoidne žlijezde).

\section{Ograničenja i kontraindikacije hitnih biopsija}

Hitne biopsije mogu biti potencijalno štetne za pacijenta: na primjer hitne biopsije male primarne lezije koja bi bila smrznuta u cijelosti. Umjetno izobličenje ili gubitak tkiva može onemogućiti dijagnozu. Hitnu biopsiju posebno se treba izbjegavati u slučajevima pigmentiranih kožnih lezija i malih lezija dojke ${ }^{1}$.

Ponekad, hitna biopsija može imati nisku senzitivnost ili specifičnost, na primjer, kod folikularnih lezija štitnjače i procjeni kapsularne invazije, ili

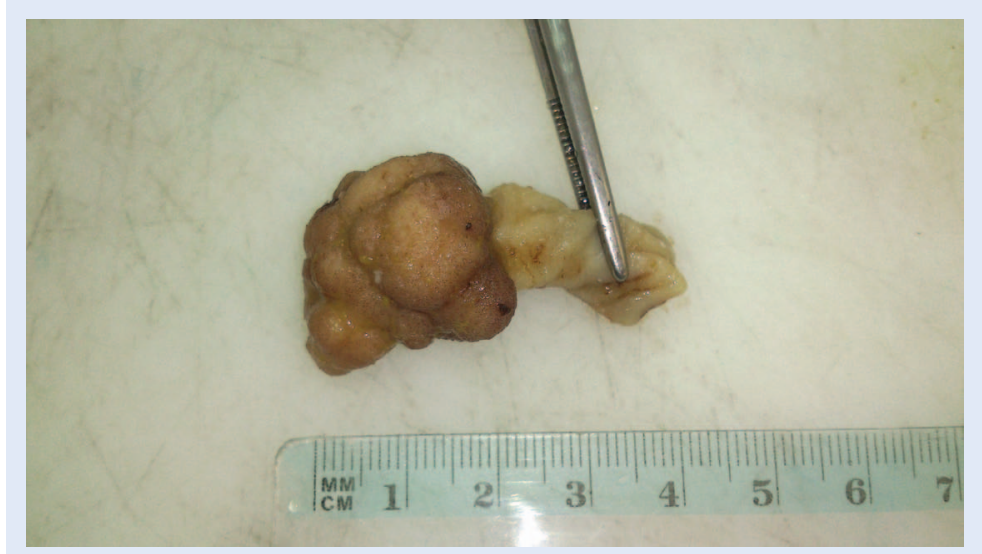

Slika 2. Primjer ekscizijske biopsije: pedunkularni polip debelog crijeva promjera $2 \mathrm{~cm}$, odstranjen u jednom aktu, s vidljivom peteljkom duljine $2 \mathrm{~cm}$.

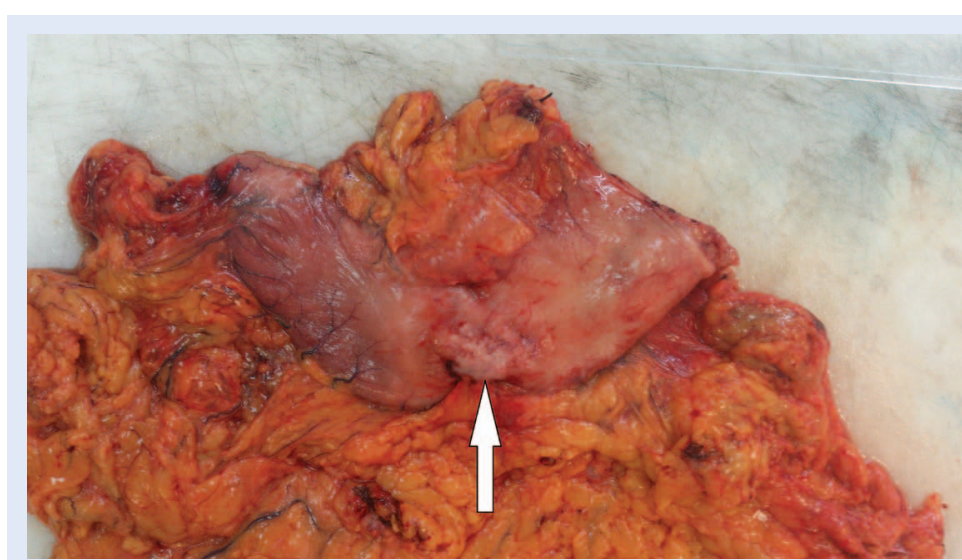

Slika 3. Kirurška resekcija želuca s masnim tkivom uz malu krivinu i omentumom. U središnjem dijelu velike krivine vidi se bjelkasti tumor koji uvlači serozu (strelica).

kod reeksicizija dojke u identifikaciji intraduktalnog karcinoma na resekcijskom rubu.

Ako se radi hitna biopsija, kirurg mora biti svjestan mogućnosti da se dijagnoza može promijeniti kad se naprave trajni parafinski rezovi.

\section{Tehnički problemi hitnih biopsija}

- artefakti smrzavanja uzrokuju oštećenja tkivne strukture u hitnim biopsijama;

- smrznuti rezovi lošije su kvalitete od parafinskih rezova; oni su obično deblji, mogu biti preklopljeni, ispod pokrovnog stakalca može ući zrak, pa se teže vizualiziraju histološke promjene;

- „napuhnuta” stanična morfologija u smrznutim rezovima, što patolog mora imati na umu;

- slabije i lošije obojeni tkivni rezovi, što utječe na analizu i procjenu izgleda lezije². 
Hitna ili intraoperacijska biopsija je hitno stanje u patologiji koje zahtijeva dobru suradnju između kirurga i patologa te iskusnog i dobro educiranog patologa koji je svjestan mogućnosti, ali i ograničenja hitne biopsije.

Jedan od najvažnijih ciljeva kirurške patologije je dijagnostika malignih bolesti i procjena proširenosti bolesti, odnosno klasifikacija tumora, prema odrednicama Svjetske zdravstvene organizacije. Patološka klasifikacija malignih bolesti označava se kao pTNM (primarni tumor - T, regionalni limfni čvorovi - N, udaljene metastaze - M). Ona se temelji na podacima dobivenim prije kirurškog liječenja uz modifikaciju proizašlu iz patohistološke analize tkiva.

\section{PUT OD UZORKA TKIVA DO HISTOLOŠKOG}

\section{PREPARATA}

Postoje četiri glavna koraka koja su uobičajena u skoro svim histološkim procedurama. Prvo, uzorak se fiksira da bi se očuvalo tkivo i usporila njegova degradacija. Nakon toga, patolog pregledava i preuzima isječke tkiva koji se uklapaju u medij sličnih mehaničkih karakteristika kao i tkivo. I na kraju, uzorak se reže na tanke listiće koristeći se preciznim uređajem, koji se zove mikrotom i oboji rutinski hemalaun eozinom (HE). Zalijepi se pokrovno stakalce i tako se dobije konačni histološki preparat koji dolazi patologu na stol za analizu putem svjetlosnog mikroskopa.

Od izuzetnog je značaja vrijeme koje prođe od uzimanja tkiva u trenutku prekidanja njegove opskrbe krvlju do trenutka fiksacije - VRIJEME HLADNE ISHEMIJE. U tom vremenu dolazi do degradacije tkiva primarno procesom autolize (autodigestija enzimima koje se nalaze u stanicama) koja započinje trenutno. Ovaj proces ubrzava povišena temperatura u okolini.

Vrijeme hladne ishemije utječe na morfologiju tkiva i rezultate imunohistokemijskih i in situ hibridizacijskih analiza. Ovo vrijeme trebalo bi biti što je kraće moguće, ne više od jednog sata. Štetni efekt odgođene fiksacije uključuju pojačanu, smanjenu ili delokaliziranu imunoreaktivnost.

\section{Fiksacija tkiva}

Tkivna fiksacija je važan i kritičan korak koji služi očuvanju stanica i tkiva i održava njihovu strukturu. Nakon stanične smrti se oslobađaju enzimi iz staničnih organela i uništavaju strukturu stanice. Jedan od najčešće korištenih fiksativa je formalin - odnosno vodena otopina formaldehida. Tijekom fiksacije formaldehid se veže za postranične lance proteina stvarajući stabilnu vezu zvanu „metilenski most”. Ovaj proces je prirodno spor i može trajati jedan do dva dana.

Fiksativu, kojemu je potreban jedan sat da penetrira $1 \mathrm{~mm}$ u tkivni uzorak, treba 25 sati da penetrira $5 \mathrm{~mm}$. Jednom kad je formalin dosegao središnji dio tkiva, treba se još dovršiti reakcija unakrsnog povezivanja. S obzirom na te činjenice, uzorak tkiva treba biti oko $4-5 \mathrm{~mm}$ debljine za temeljitu fiksaciju u razumnoj količini vremena.

Drugo, treba uzeti u obzir volumen i pH fiksativa. Omjer fiksativa i uzorka tkiva trebao bi biti najmanje $40: 1$ da reagens ne bi bio iscrpljen tijekom vremena.

Fiksacija je najvažnija preparativna histološka tehnika. Posljedice slabe fiksacije NE MOGU se više ispraviti u kasnijim stadijima preparacije tkivnih uzoraka.

Fiksirani uzorak tkiva se makroskopski pregledava i preuzima.

\section{Uklapanje}

Sljedeći korak u histološkoj pripremi tkiva je uklapanje, koje podrazumijeva stavljanje uzorka tkiva u medij koji ima sličnu mehaničku rigidnost, odnosno čvrstoću kao i samo tkivo. Danas je najučestaliji medij za uklapanje parafinski vosak. Uklopljeni uzorci stavljaju se u tkivne kazete za rezanje.

\section{Rezanje}

Rezanjem se dobivaju tanke kriške ili listići tkiva iz parafinske kocke. Rezovi tkiva su obično debljine 4- $6 \mu \mathrm{m}$ za korištenje u svjetlosnoj mikroskopiji.

\section{Bojenje}

Biološka tkiva imaju vrlo malo prirodnog kontrasta, tako da se tkivni rezovi nakon sušenja moraju obojiti da bi, gledajući svjetlosnim mikroskopom, bila vidljiva tkivna morfologija. Uobičajeno, rutin- 
sko bojenje koje se koristi je hemalaun i eozin. Hemalaun oboji jezgre stanica plavo, a eozin oboji citoplazmu ružičasto, otkrivajući tako tkivnu morfologiju.

Svaki korak vrlo je važan jer pridonosi kvaliteti patohistološkog preparata i njegove analize, a to $u$ konačnici znači - postavljanje ispravne dijagnoze.

\section{DIJELOVI KIRURŠKE PATOLOGIJE}

Četiri su glavna dijela kirurške patologije koja se koriste u konačnoj dijagnostici tkivnih uzoraka: makroskopski pregled, patohistološki pregled koji se temelji na svjetlosnoj mikroskopiji, imunohistokemija i molekularne/citogenetske analize.

\section{Makroskopski pregled}

Makroskopski pregled je pregled uzorka golim okom i predstavlja prvi nivo kirurške patologije. Dobar makroskopski pregled uzorka je kritični dio patološke dijagnostike. Klinički podaci izrazito su važni jer pomažu i vode patologa u dijagnostičkom pregledu i interpretaciji promjena u primljenom uzorku³. Dva su konačna produkta makroskopskog pregleda kirurškog uzorka tkiva: makroskopski opis i uzorkovanje tkiva u vidu tkivnih blokova.

Makroskopski opis je važan medicinsko-pravni dokument. Temelji se na opisu tkiva ili organa koristeći se opisnim pojmovima koji ukazuju na di-

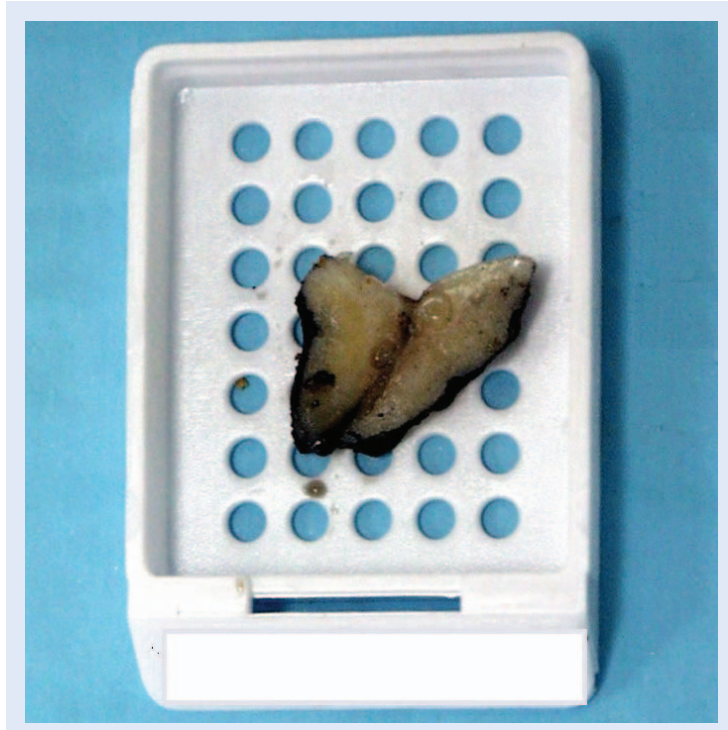

Slika 4a. Primjer tkivnog bloka - preuzeti isječak konizata vrata maternice $s$ tušem označenim kirurškim rubovima. ferencijalne dijagnoze, a ne konačne dijagnoze. Primljeni kirurški materijal mora se izmjeriti u cijelosti, kao i eventualno vidljive patološke promjene, uz procjenu udaljenosti lezije od resekcijskog ruba. Budući da se pri pregledu i uzorkovanju velikih kirurških materijala samo mali isječci (tkivni blokovi) mogu mikroskopski pregledati, uspjeh konačne patohistološke dijagnoze uvelike ovisi o profesionalno izvedenom makroskopskom pregledu. Uzorkovanje tkiva u vidu tkivnih blokova, obično veličine poštanske marke, stavlja se u plastične kazete (slika 4a), koje se onda procesuiraju do histoloških preparata za mikroskopsku analizu. Pri tome se mogu uzimati uzorci tkiva i za neke dodatne analize, kao što je, primjerice, elektronska mikroskopija. Na ovaj se način mogu dobiti dijagnostički važne informacije o stadiju bolesti i statusu resekcijskih rubova kirurški odstranjenih tkiva i/ili organa.

\section{Patohistološki pregled}

Patohistološki pregled podrazumijeva mikroskopsku analizu histoloških preparata svjetlosnim mikroskopom (slika 4b). Tijekom mikroskopiranja patolog uzima u obzir kliničke podatke i makroskopsku sliku, odnosno izgled tkiva i lezije. Ponekad su potrebne dodatne analize, odnosno posebna bojenja - imunohistokemija.

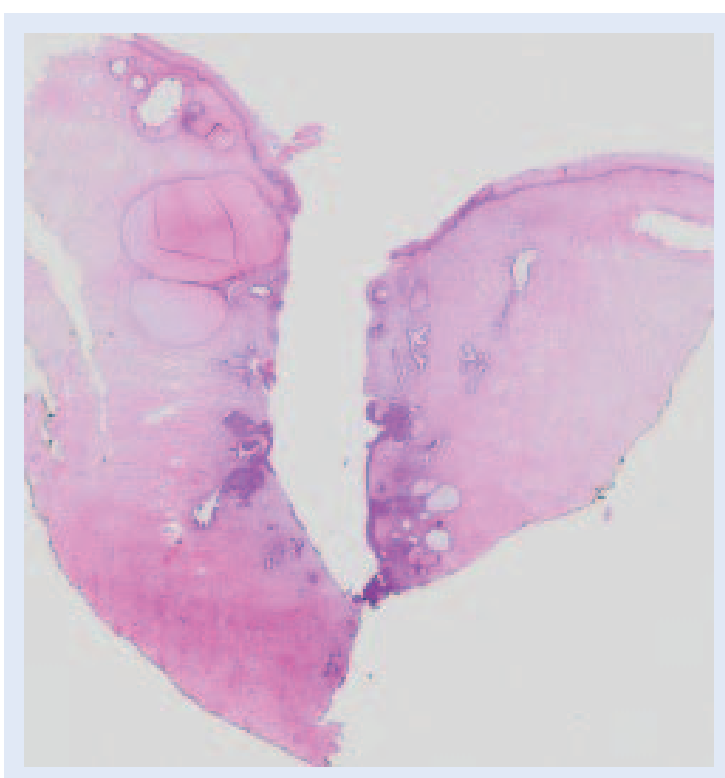

Slika 4b. Primjer histološkog preparata konizata vrata maternice obojenog HE. 


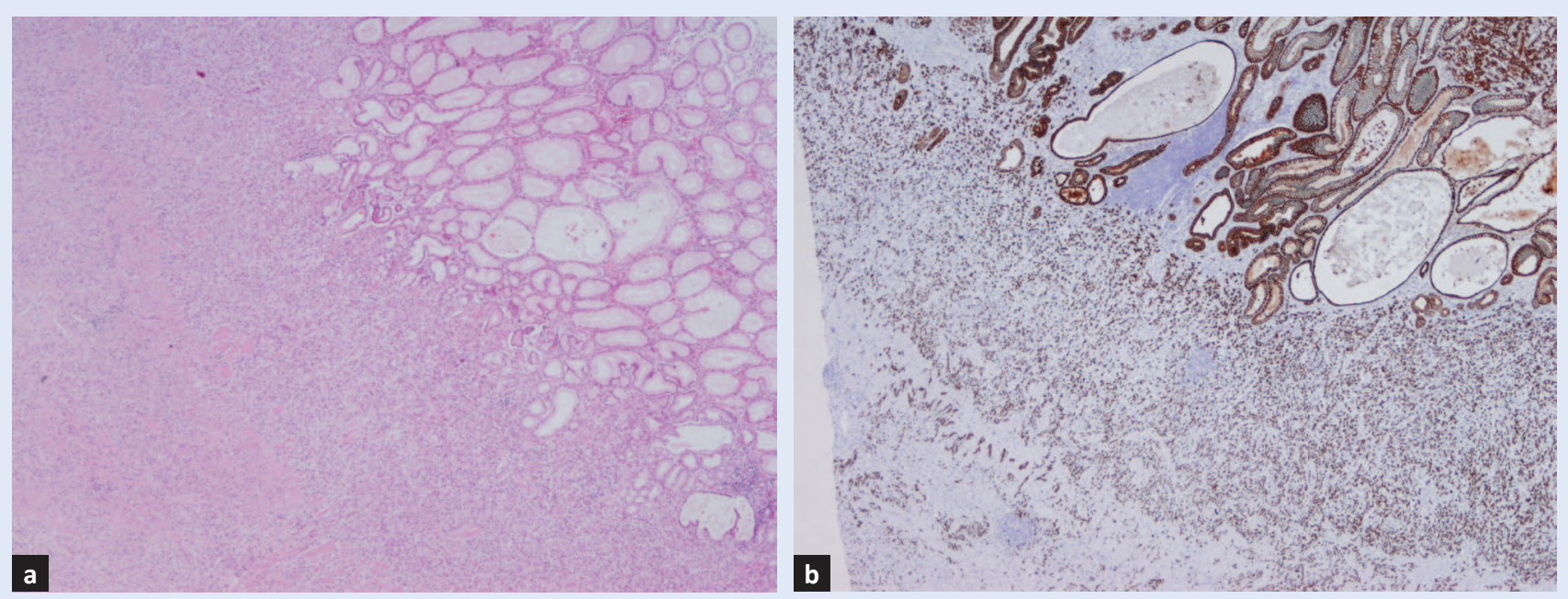

Slika 5. Histološki preparat (obojen HE) sluznice želuca infiltriran tumorskim tkivom (a), koje se bolje vizualizira na preparatu obojenom imunohistokemijski citokeratinom (b), koji oboji epitel sluznice i tumorske stanice smeđe.

\section{Imunohistokemijska analiza}

Imunohistokemijska analiza patologu omogućava precizniju dijagnozu (slika 5), ili diferencijalnu dijagnozu. Imunohistokemija se odnosi na proces otkrivanja antigena u stanicama tkiva, koristeći se pritom principima specifičnog vezanja antitijela za antigene.

\section{Molekularna patologija}

Molekularna patologija dio je patologije koji analizira molekule deoksiribonukleinske kiseline (DNK), ribonukleinske kiseline (RNK) i proteine. Može se testirati prisutnost ili odsutnost proteina ili RNK-a, odnosno povećanje ili smanjenje količine ovih molekula. Osim toga, mogu se otkriti specifične mutacije gena ${ }^{4}$.

U svrhu ciljane terapije tzv. „pametnim lijekovima" i primjene personalizirane medicine koriste se molekularni testovi koji imaju prediktivni značaj u odgovoru na terapiju kod određenih oblika malignih tumora. Tako se HER2 (engl. human epidermal growth factor receptor 2) testiranje rabi kod karcinoma dojke i želuca, KRAS i NRAS kod karcinoma debelog crijeva, EGFR (engl. epidermal growth factor receptor) kod karcinoma pluća, BRAF kod melanoma.

\section{ZNAČAJ KLINIČKIH PODATAKA}

Klinički podaci i komunikacija između kliničara i patologa od osobite je važnosti. Patolog ne može samo na temelju mikroskopskog pregleda tkiva dati kliničaru sve podatke koji su neophodni za eventualnu prognozu i daljnje liječenje ${ }^{5}$. Zato je bitan makroskopski pregled i uzorkovanje tkivnih isječaka, pri čemu kritičnu ulogu imaju klinički podaci, koji usmjeravaju patologa u radu. Adekvatni klinički podaci uključuju:

- svrhu kirurškog odstranjivanja uzorka tkiva ili resekcije (dijagnostička biopsija, resekcija tumora ili reekscizija ležišta tumora...)

- makroskopski izgled i smještaj određene patološke tvorbe/tumora (npr. maligni tumori ne moraju biti makroskopski vidljivi nakon provedene neoadjuvantne terapije),

- prethodne dijagnoze (vrsta tumora i stadij),

- prethodnu ili trenutnu terapiju (radio- ili kemoterapija koja mijenja morfologiju tkiva imitirajući maligne promjene; lijekovi koji isto tako mogu promijeniti histologiju tkiva),

- orijentaciju kirurškog uzorka (kirurškim šavima, tušem u boji, orijentacijom na printanoj shemi...) zbog pravilne procjene smještaja tumora u uzorku i određivanja njegovog odnosa prema kirurškim resekcijskim rubovima.

\section{PROCJENA PROŠIRENOSTI BOLESTI} (STADIJA BOLESTI)

Jedan od najvažnijih ciljeva kirurške patologije je dijagnostika malignih bolesti, odnosno klasifikacija tumora (premalignih i malignih lezija) i procjena proširenosti bolesti. To se radi prema odrednicama Svjetske zdravstvene organizacije, koja za svako 
područje patologije organskih sustava ima svoje definicije ${ }^{6}$.

Da bi se odredila vrsta tumora, potrebno je analizirati morfologiju tumora i odrediti histotip.

American Joint Committee on Cancer ili AJCC za određivanje stadija koristi TNM klasifikacijski sustav, pri čemu se karcinomu pridružuje određeno slovo. Slovo ' $T$ ' (engl. tumor) označava veličinu karcinoma, slovo 'N' (engl. node, što znači čvor) zahvaćenost regionalnih limfnih čvorova karcinomom i slovo ' $\mathrm{M}$ ' (engl. metastasis) prisutnost karcinoma u udaljenom sijelu, odnosno prisutnost udaljenih metastaza.

Postoji više klasifikacija koje se danas koriste. Jedna je klinička klasifikacija ili klinički (c) TNM, a temelji se na određivanju stadija prije kirurškog liječenja, odnosno na raznim kliničkim testovima i biopsiji, a označava se kao cTNM.

Druga klasifikacija je patološka klasifikacija, a označava se kao pTNM. Ona se temelji na podacima dobivenim prije kirurškog liječenja, odnosno na cTNM-u, uz modifikaciju proizašlu iz patohistološke analize tkiva.

Postoji klasifikacija koja u obzir uzima status tumora nakon provedene terapije (kirurške, kemoterapije ili multimodalne terapije), takozvana klasifikacija rezidualnog tumora - $\mathbf{R}$ klasifikacija. Ona utječe na daljnju terapiju i snažni je prediktor prognoze.

Zbog pobližeg definiranja posebnih slučajeva unutar cTNM ili pTNM klasifikacije, koriste se sljedeći simboli:

- m simbol koristi se kao sufiks u zagradi i pokazatelj je multiplih tumora jednog sijela,

- y simbol koristi se kao prefiks u cTNM ili pTNM klasifikaciji, a označava proširenost tumora nakon provedene neoadjuvantne terapije; u obzir uzima samo vijabilno tumorsko tkivo, a ne znakove regresije tumora,

- $r$ simbol se kao prefiks koristi u klasifikaciji recidivnih tumora nakon kurativne terapije,

- a simbol se kao prefiks koristi u određivanju stadija prilikom obdukcije (autopsije).

\section{Primarni tumor (pT)}

Slovo ' $T$ ' iza kojeg slijedi broj od 0 do 4 opisuje karakteristike tumora: njegovu veličinu i proširenost. Veći broj uz slovo ' $\mathrm{T}$ ' upućuje na veći tumor

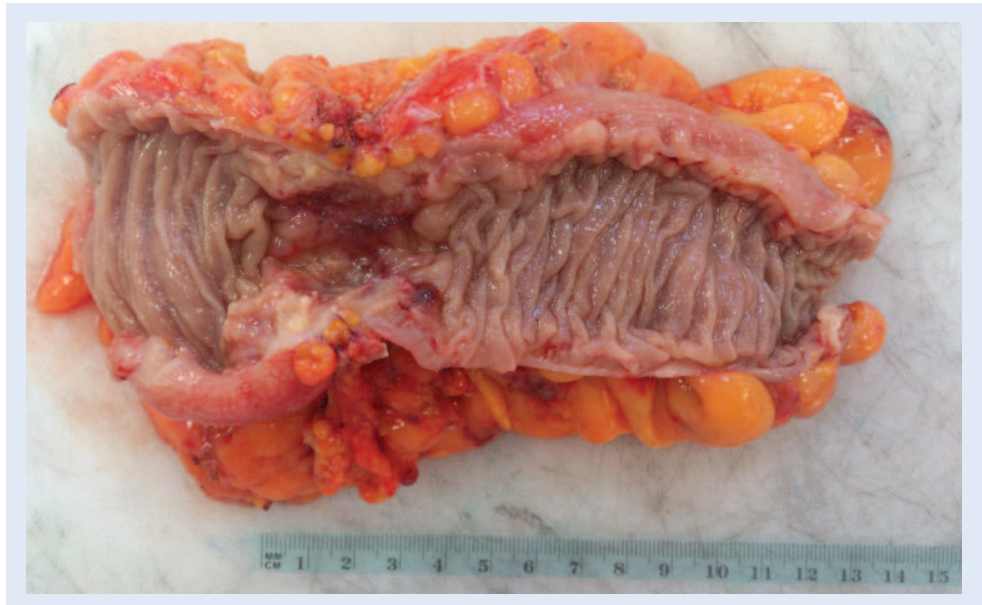

Slika 6a. Isječak debelog crijeva s karcinomom u obliku egzulcerirane tvorbe, duljine $4 \mathrm{~cm}$, koji zahvaća cijelu cirkumferenciju stijenke. U ovom slučaju veličina tumora određuje se makroskopski.

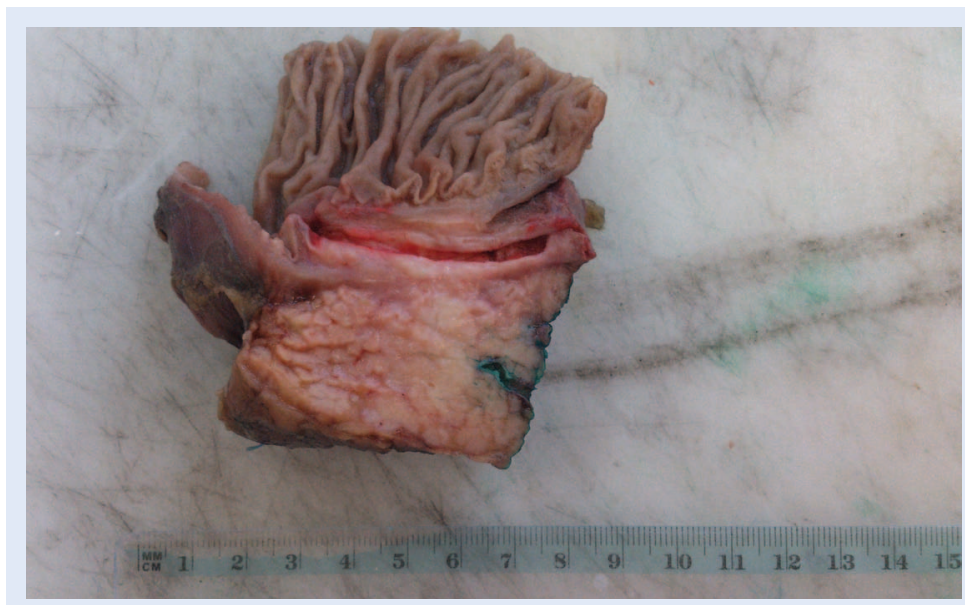

Slika 6b. Isječak glave pankreasa sa stijenkom duodenuma. U glavi pankreasa nalazi se karcinom koji opstruira Wirsungov kanal (obojen zelenim tušem), a makroskopski je vrlo teško vidljiv. Pažljivim preuzimanjem tkiva s numeriranjem kazeta može se mikroskopski procijeniti veličina i proširenost karcinoma.

i/ili proširenost u okolne strukture. Veličina tumora je mjera koja se najčešće određuje pri makroskopskom pregledu tkiva ili organa (slika 6 a), iako se ponekad veličina mora procijeniti mikroskopski, jer je tumor vrlo slabo vidljiv golim okom, npr. karcinom pankreasa (slika 6 b) ili prostate.

\section{Regionalni limfni čvorovi (pN)}

Slovo ' $N$ ' iza kojeg slijedi broj od 0 do 3 označava proširenost karcinoma u regionalne limfne čvorove. U tu se svrhu detaljno pregledava masno tkivo u okolici tumora (pod uvjetom da je izvađeno) i iz njega se izoliraju limfni čvorovi, 
odredi im se veličina i broj, a mikroskopskim pregledom ustanovi broj metastatskih limfnih čvorova.

\section{Udaljene metastaze (pM)}

Slovo ' $M$ ' iza kojeg slijede brojevi 0 ili 1 označava prisutnost metastaza u udaljenim organima. Radi se o hematogenom rasapu malignog tumora, a mjesta metastaziranja su najčešće jetra, pluća, kosti i mozak.

\section{PROCJENA KIRURŠKIH RUBOVA}

Kod uzoraka tkiva dobivenih kirurškom resekcijom vrlo je važno procijeniti udaljenosti tumora od ruba resekcije (kirurškog ruba), odnosno procijeniti nalazi li se tumor na rubu ili ne.

U tu se svrhu resekcijski rubovi oboje tušem, što se posljedično vidi i pri mikroskopskom pregledu

\section{MEDII}

Datum uzimanja uzorka:

Datum prijema:

Datum zakljucienja

Preparate izradio:

KLINIĆKI BOLNIĆKI CENTAR - RIJEK

SALA $1 Z$

Liječnik:

\section{BIOPTIČKI BROJ:}

\section{PREZIME I IME:}

SPOL:

UPUTNA DIJAGNOZA:

5051 - Biopsija

Anamneza: Dg: Npl recti Op: Resectio recti anterioris per lap.

Materijali: crievo sa mezenterijem; masno tkivo mezorektuma

Dijagnoza: C20 - Zloćudna novotvorina završnog debelog crijeva (rektuma)

MAKROSKOPSKI OPIS:

1. Vrsta uzorka: rektum duljine $11 \mathrm{~cm}$, dva prstenasta isječka

Smještaj tumora: na $1 \mathrm{~cm}$ od ruba resekcije

Tumorski oblik: krater uzdignutih rubova

Tumorska veličina $(\mathrm{u} \mathrm{cm}): 2.5 \mathrm{~cm}$, zauzima $65 \%$ cirkumferencije

Mezorektum: infiltriran

2. Kao "masno tkivo mezorektuma" primljena su tri isječka masnog tkiva ukupne veličine $2 \times 2 \times 1 \mathrm{~cm}$

MIKROSKOPSKI OPIS:

1. Histolośki tip: adenokarcinom

Histološki gradus: niski

Dubina invazije: svi slojevi stienke, infiltrira okolno masno thivo

Regionalni limfni čvorovi: $0 / 7$

Udaljene metastaze: I

Kirurški rubovi i prstenovi: bez tumora

Perforacija crijeva: ne

Limfovaskularna invazija: nije nađena

Perineuralna invazija: da

imfocitni infiltrat oskudan

Oblik tumorskog ruba: infiltrativan

Neneoplastično crijevo: bez osobitost

Neneoplastično

2. Masno tkivo uredne građe, bez limfnih čvorova i bez tumora

ADENOCARCINOMA RECTI, Dukes B, pT3, pNO

Slika 7. Primjer strukturiranog patohistološkog nalaza tkiva. Na taj se način može točno izmjeriti udaljenost tumora od kirurškog ruba. Neadekvatni kirurški rubovi koreliraju s recidivom bolesti. Definicija pozitivnog kirurškog ruba ovisi o vrsti tumora, njegovoj biologiji i anatomskoj lokalizaciji lezije.

\section{PATOHISTOLOŠKO IZVJEŠĆE}

Rezultat rada patologa je patohistološko izvješće. Ono sadrži makroskopski i mikroskopski opis tumora, dijagnozu ili diferencijalnu dijagnozu. Može biti napisano u obliku strukturiranog nalaza (slika 7) ili opisno.

Adekvatno kirurško patohistološko izvješće ima četiri glavna elementa kvalitete: vremenski dobru tempiranost, točnost, cjelovitost $\mathrm{i}$ iskoristivost. Izvješće treba sadržavati sve bitne informacije potrebne za dijagnozu, prognozu i odluke o daljnjoj terapiji ${ }^{7}$.

Strukturirano patohistološko izvješće lakše je i jednostavnije čitati od onoga napisanog u obliku opisnog teksta, a u isto vrijeme se minimalizira rizik pogrešne interpretacije i kliničke pogreške. $\mathrm{Na}$ taj način predstavlja osnovu boljeg sporazumijevanja između kliničara i patologa.

Izjava o sukobu interesa: Autorica izjavljuje da ne postoji sukob interesa.

\section{LITERATURA}

1. Lester SC. Manual of Surgical Pathology. 2nd Edition. Boston: Elsevier Churchill Livingstone, 2006.

2. Jaafar H. Intra-Operative Frozen Section Consultation: Concepts, Applications and Limitations. Malays J Med Sci 2006;13:4-12.

3. Nakhleh RE, Zarbo RJ. Surgical pathology specimen identification and accessioning-A College of American Pathologists Q-Probes study of 1,004,115 cases from 417 institutions. Arch Pathol Lab Med 1996;120: 227-33.

4. Heriot K. Practical Surgical Pathology. Integrating Molecular Pathology into Your Morphologic Practice. Chicago: American Societiy for Clinical Pathology Press, 2013.

5. Bull AD, Cross SS, James DS, Silcocks PB. Do pathologists have extrasensory perception? BMJ 1991;303: 1604-5.

6. Bosman FT, Carneiro F, Hruban RH, Theise ND. WHO Classification of Tumours of the Digestive System, 4th Edition. Lyon, France: International Agency for Research on Cancer (IARC), 2009.

7. Srigley JR, Mcgowan T, Maclean A, Raby M, Ross J, Kramer S et al. Standardized Synoptic Cancer Pathology Reporting: A Population-Based Approach. J Surg Oncol 2009;99:517-24. 